\title{
Comparative Efficacy of Three Tomato-Associated Rhizobacteria used Singly or in Combination in Suppressing Rhizoctonia Root Rot and Enhancing Tomato Growth
}

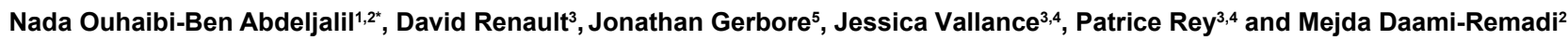 \\ ${ }^{1}$ Higher Agronomic Institute of Chott-Mariem, Sousse University, Tunisia \\ ${ }^{2}$ UR13AGR09- Integrated Horticultural Production in the Tunisian Centre East, Regional Centre of Research on Horticulture and Organic Agriculture, University of Sousse, \\ Tunisia \\ IINRA, UMR1065 Santé et Agroécologie du Vignoble (SAVE), F-33140 Villenave d'Ornon, France \\ ${ }^{4}$ Université de Bordeaux, Bordeaux Sciences Agro, F-33140 Villenave d'Ornon, France
}

${ }^{5}$ BIOVITIS, 15400 Saint Etienne de Chomeil, France

\begin{abstract}
Three indigenous tomato-associated rhizobacteria strains -Bacillus subtilis str. B2 KT921327, B. thuringiensis str. B10 KU158884 and Enterobacter cloacae str. B16 KT921429 - were tested singly and in combination as substrate drench for Rhizoctonia Root Root suppression and plant growth promotion on two tomato cultivars during two cropping seasons. All bacteria-based treatments were found to be more effective in suppressing disease than the fungicide on both cultivars and in both cropping seasons. The disease-suppression and growth-promotion abilities of the treatments tested varied significantly depending on pathogen presence or absence, bacterial strains, tomato cultivars and cropping years. Overall, for all trials and cultivars combined, disease suppression potential, as compared to the untreated controls, ranged between 74.72 and $83.94 \%$ using three-strain mixture relative to $60.46-85.01 \%$ achieved using single strains. Height increment in disease free plants achieved with mixtures varied between 17.02 and $45.69 \%$ compared to 7.55 and $44.76 \%$ noted using single strains. Plants grown in $R$. solaniinoculated peat and challenged with three-strain mixture were 49.46 to $76.74 \%$ higher than controls whereas those grown in peat amended with single strains showed $42.28-83.58 \%$ height increase. Increment of aerial parts and root fresh weights on disease free plants were $42.31-78.09 \%$ and $45.03-91.21 \%$ for plants treated with mixture compared to $33.70-82.48 \%$ and $20.52-92.39 \%$ recorded using strains singly, respectively. On inoculated plants, these parameters were enhanced by $61.2-95.44 \%$ and $59.13-98.5 \%$ using mixed treatment and by $48.41-97.02 \%$ and by $51.5-99.05 \%$, respectively, using single-train-based treatments. Analysis of the microbial populations revealed no differences between Single Strand Conformational Polymorphism (SSCP) profiles when neither the rhizobacteriabased treatment nor the pathogen inoculation was considered. The microbial communities differed only depending on cultivars grown.
\end{abstract}

Keywords: Biocontrol; Disease suppression; Microbial community; Plant growth; Rhizoctonia solani; Strain-mixture; Tomato

\section{Introduction}

Rhizoctonia solani Kühn is one of the most economically important soil borne fungi. This fungus is frequently recovered from soils all over the world and is considered as a serious plant pathogen able to infect various crops including vegetables [1]. This fungus does not generate asexual spores and is able to persist in the soil as hyphae and sclerotia [2]. This pathogen caused pre-emergence and post emergence damping-off, collar and roots rots and subsequent plant death leading to consistent loss of production under both greenhouse and open field conditions $[3,4]$. In Tunisia, this pathogen is prevalent in many vegetable-grown fields and is responsible for serious damping-off and root rot diseases in many economically important crops [5-8].

Control of Rhizoctonia diseases was firstly achieved with cultural practices, solarization, and chemical control with the last one being the mostly used [9]. However, cultural and chemical control are not sufficiently effective in controlling disease [10] due to the wide host range of the pathogen and to survival of sclerotia under various environmental conditions [11].

The necessity to reduce energy costs in tomato and to develop more safer control methods have encouraged research efforts at finding new and effective alternatives. Whipps [12] reported that the promising use of naturally occurring antagonists for biologically controlling pathogens.
Indeed, biological control is an efficient means to prevent dampingoff disease [2,13]. Beneficial bacteria can protect plants against soil borne plant pathogens [14-16]. Rhizobacteria such as Bacillus subtilis [17], B. thuringiensis [18], and Enterobacter sp. [19] were shown to be efficient in controlling $R$. solani. Application of some bacteria in the rhizosphere led to increased plant growth through the enhancement of emergence potential, stand establishment, plant vigor, and vegetative and root weight $[20,21]$. These plant growth promoting rhizobacteria (PGPR) can display disease-suppressive ability by decreasing incidence and severity of various crown, root and foliar diseases through direct inhibition of pathogens or indirectly via the induction of systemic resistance (ISR) [14,22,23].

In most biocontrol research studies, biocontrol agents (BCAs) are

*Corresponding author: Nada Ouhaibi-Ben Abdeljalil, Higher Agronomic Institute of Chott-Mariem, Sousse University, Tunisia, Tel: 0021673327534 ; E-mail: nadouhaibi@hotmail.fr

Received January 30, 2016; Accepted February 17, 2016; Published February 27, 2016

Citation: Ouhaibi-Ben Abdeljalil N, Renault D, Gerbore J, Vallance J, Rey P, et al. (2016) Comparative Efficacy of Three Tomato-Associated Rhizobacteria used Singly or in Combination in Suppressing Rhizoctonia Root Rot and Enhancing Tomato Growth. J Microb Biochem Technol 8: 110-119. doi: 10.4172/19485948.1000272

Copyright: (c) 2016 Ouhaibi-Ben Abdeljalil N, et al. This is an open-access article distributed under the terms of the Creative Commons Attribution License, which permits unrestricted use, distribution, and reproduction in any medium, provided the original author and source are credited. 
Citation: Ouhaibi-Ben Abdeljalil N, Renault D, Gerbore J, Vallance J, Rey P, et al. (2016) Comparative Efficacy of Three Tomato-Associated Rhizobacteria used Singly or in Combination in Suppressing Rhizoctonia Root Rot and Enhancing Tomato Growth. J Microb Biochem Technol 8: 110-119. doi: 10.4172/1948-5948.1000272

often applied singly to combat the growth of targeted pathogens [24,25]. Potential effectiveness of single BCAs has been largely demonstrated in many studies but their single use under field conditions may lead to inconsistent performance as these agents are not likely to be active in all kinds of soil environment and agricultural ecosystems [26]. Several approaches have been used to overcome these practical problems, including combined application of two or more biocontrol strains to enhance their level of effectiveness and to achieve consistency of disease suppression [27-31]. Thus, more emphasis was laid on the combined use of two or more biocontrol strains for improved effectiveness than either of them alone [32,33].

After in vivo and in planta biocontrol agents' release, it is interesting to analyze the microbial community (fungal and bacterial community) around and within roots of treated plants and to determine the eventual changes that may occur following biocontrol treatments. To this end, the knowledge of microbial ecology of the target habitat is necessary for accurate study of the relationship between microorganisms. The microbial activity and diversity has been widely analyzed using common cultivation techniques but recently several DNA-based analyses, cultivation-independent methods, were performed and are being extensively used to overcome the limitations of cultivation techniques [11].

In previous study, we selected three tomato-associated rhizobacterial strains out of 25 tested for their ability to inhibit Sclerotinia sclerotiorum in vitro, to suppress Scletrotinia Stem Rot severity and to enhance tomato plant growth [8]. The three most promising strains identified as Bacillus subtilis str. B2 (KT921327), B. thuringiensis str. B10 (KU158884) and Enterobacter cloacae str. B16 (KT921429) were selected in order to assess their antagonistic activity toward other soilborne fungi infecting tomato. Thus, our study aimed i) to assess the comparative ability of the three selected strains, applied singly or in combination, to suppress Rhizoctonia Root Rot disease on two tomato cultivars and to enhance plant growth, and ii) to study the effects of the rhizobacteria-based treatments on pathogen population colonizing the rhizosphere and to follow up fungal dynamics throughout the two tomato cultivars grown using Single Strand Conformational Polymorphism (SSCP) investigations.

\section{Materials and Methods}

\section{Plant material}

For biocontrol experiments and the elucidation of the subsequent shifts in the rhizospheric microbial community, 21-day-old tomato (cvs. Marmande and Rio Grande) seedlings were used. Seeds were surfacesterilized with $2 \%$ sodium hypochlorite for $2 \mathrm{~min}$, washed thoroughly with sterile distilled water (SDW), and sown into disinfected dimpled plates containing sterile peat. Tomato seedlings were grown in a greenhouse at $13 / 11 \mathrm{~h} \mathrm{light/dark}$ photoperiod and $21 / 18 \pm 2{ }^{\circ} \mathrm{C}$ light/ dark temperature and regularly watered until being used for the in vivo trials.

\section{Pathogen inoculum preparation}

Pathogen isolate used was originally isolated from naturally infected tomato plants exhibiting typical Rhizoctonia Root Rot signs. The fungal culture was gratefully provided by the Plant Pathology Laboratory at the Regional Center of Research on Horticulture and Organic Agriculture of Chott-Mariem, Tunisia. Cultures were grown on potato dextrose agar (PDA) medium and stored at $4^{\circ} \mathrm{C}$ until use. For inoculum production, ten PDA Petri plates $(9 \mathrm{~cm}$ in diameter) covered with full mycelium growth of pathogen cultures previously grown on PDA for 5-6 days at $28^{\circ} \mathrm{C}$, were macerated using a blender in $1 \mathrm{~L}$ of SDW. Inoculum suspension was adjusted at $10^{8}$ mycelial fragments per ml using a Malassez haemocytometer [30].

\section{Tomato-associated rhizobacterial strains tested and inoculum preparation}

Three rhizobacterial strains namely Bacillus subtilis str. B10 (KT921327), B. thuringiensis str. B2 (KU158884), and Enterobacter cloacae str. B16 (KT921429), selected in a previous study [8] based on their ability to suppress Sclerotinia Stem Rot and to promote tomato growth, were used in the current investigation.

The rhizobacterial cultures were initiated by streaking the stock cultures onto Nutrient Agar (NA) medium and incubated at $28^{\circ} \mathrm{C}$ for $24 \mathrm{~h}$ before use. A loop-full of each bacterial strain was suspended into $300 \mathrm{ml}$ of Nutrient Broth (NB) and incubated in a rotary shaker at $175 \mathrm{rpm}$ for $48 \mathrm{~h}$ at $28^{\circ} \mathrm{C}$. After incubation, $300 \mathrm{ml}$ of the obtained bacterial liquid culture was diluted into $1 \mathrm{~L}$ of SDW and adjusted to approximately $10^{8} \mathrm{CFU} \mathrm{ml^{-1 }}$ before being used for plant challenge [34]. For mixed inoculum preparation, equal volumes of cell suspensions of each bacterial strain were mixed and the formulation obtained was used for plant treatment.

\section{Plant inoculation and treatment}

For the bioassays, 21-day-old tomato cvs. Rio Grande and Marmande seedlings grown into dimpled plates containing sterile peat were used. They were left to dry for two days before being treated. Seedlings' treatment was performed as substrate drenching at the collar level using $30 \mathrm{ml}$ of the bacterial cell suspension of either single strains or their mixture $\left(10^{8} \mathrm{CFU} \mathrm{ml}{ }^{-1}\right)$. One week post bacterial treatment, $30 \mathrm{ml}$ of pathogen inoculum were poured at the same level to each seedling. One day post pathogen challenge, seedlings were transplanted into pots (16 cm in diameter) containing pathogen-infected peat [35].

Untreated and uninoculated control seedlings were watered with SDW only. Pathogen-inoculated seedlings treated with SDW or with a commercial fungicide, i.e. Previcur Energy ${ }^{\mathrm{TN}}$ (632.6 g/l Propamocarb$\mathrm{Hcl}+332.6 \mathrm{~g} / \mathrm{l}$ Fosethyl-Al) applied at $0.5 \mathrm{ml} . \mathrm{l}^{-1}$, were used as controls. Uninoculated seedlings challenged with single or mixed bacterial strains were also used for comparison and for elucidation of their PGPR effect.

Pots were kept under greenhouse conditions $(65 \% \mathrm{RH}, 13 / 11 \mathrm{~h}$ light/dark photoperiod at $21 \pm 2 / 18 \pm 2^{\circ} \mathrm{C}$ light/dark temperature) till the end of the experiment. The whole experiment was repeated for two consecutive years (2012 and 2013).

\section{Parameters noted}

Two months after inoculation and treatment, the plant height and the aerial parts and roots fresh weights were recorded. Disease severity on collar and roots was also assessed using a $0-5$ scale where: $0=$ no symptom, $1=0-25 \%$ of root browning, $2=26-50 \%$ of root browning, $3=51-75 \%$ of root browning, $4=76-100 \%$ of root browning, and $5=$ plant death [15]. Disease incidence was also estimated using the following formula:

$$
\text { Disease incidence }(\mathrm{DI})(\%)=\frac{\text { Number of infected plants } * 100}{\text { Total number of plants }}
$$

\section{Statistical analysis}

The results were subjected to one-way analysis of variance and means separations were carried out using the Duncan's Multiple 
Citation: Ouhaibi-Ben Abdeljalil N, Renault D, Gerbore J, Vallance J, Rey P, et al. (2016) Comparative Efficacy of Three Tomato-Associated Rhizobacteria used Singly or in Combination in Suppressing Rhizoctonia Root Rot and Enhancing Tomato Growth. J Microb Biochem Technol 8: 110-119. doi: 10.4172/1948-5948.1000272

Range test at $(P \leq 0.05)$. ANOVA analysis was performed using SPSS version 16.0 for all disease and plant growth parameters. The tests were conducted according to a completely randomized design where 11 individual treatments were tested. Each individual treatment was replicated 15 times. The whole experiment was repeated twice. The relationships between Rhizoctonia Root Rot index and plant growth parameters were compared using Pearson's correlation analysis at $P \leq 0.05$.

\section{DNA extraction from root samples}

Root samples were taken from each individual treatment. Fifteen plants were tested and for each sample, roots were cut into fragments ( $5 \mathrm{~mm}$ in length) then kept frozen in a $-20^{\circ} \mathrm{C}$ freezer rack $(1 \mathrm{~g}$ root segments per sample) before being subsequently used for microbial and molecular analyses.

Total DNA was extracted from $60 \mathrm{mg}$ of root tissues as reported by Godon et al. [36] with slight changes. Briefly, samples were freeze-dried overnight at $-80^{\circ} \mathrm{C}$ and lyophilized for $12 \mathrm{~h}$. Six hundred $\mu \mathrm{l}$ of CTAB (1x) was added to each sample. After incubation at $65^{\circ} \mathrm{C}$ for $1 \mathrm{~h}, 400 \mu \mathrm{l}$ of chloroform-isoamyl alcohol $(24: 1, \mathrm{v} / \mathrm{v})$ was added to remove proteins, and shaken at $200 \mathrm{rpm}$ for $10 \mathrm{~min}$, and then samples were centrifuged at $13,000 \mathrm{rpm}$ for $10 \mathrm{~min} / 4^{\circ} \mathrm{C}$. The aqueous phase was transferred into another tube, and $330 \mu \mathrm{l}$ of cold isopropanol was added. Samples were then kept at $-20^{\circ} \mathrm{C}$ overnight for DNA precipitation. After $10 \mathrm{~min}$ centrifugation at $13,000 \mathrm{rpm} / 4^{\circ} \mathrm{C}$, the supernatant was discarded and $800 \mu \mathrm{l}$ of ethanol $70 \%$ was added to wash the DNA. Once the ethanol was discarded at $13,000 \mathrm{rpm} / 4^{\circ} \mathrm{C}$ for $10 \mathrm{~min}$, the pellets were air-dried and suspended into $100 \mu \mathrm{l}$ of SDW. DNA concentration was estimated using Nano-drop (ND-1000, Thermoscientific) and homogenized at a concentration of $10 \mathrm{ng} / \mu \mathrm{l}$.

\section{Analysis of rhizosphere fungal and bacterial community}

Pairs of universal primers recognizing mitochondrial large-subunit rDNA (ML1/ML2) [37] gene and the variable regions V5-V6 of the 16S rRNA (799F/1115R) [38] were used for Capillary ElectrophoresisSingle Strand Conformation Polymorphism (CE-SSCP) analysis of the fungal and bacterial community, respectively (Table 1). PCR was performed on DNA extracts from the 165 root samples collected. DNA was amplified by PCR in a PTC-100 thermocycler (MJ Research, Inc.) in a reaction mixture (30 $\mu$ l final volume) consisting of $1 \mu \mathrm{l}$ of DNA template $(10 \mathrm{ng} / \mu \mathrm{l}), 2.5 \mu \mathrm{l}$ of Taq polymerase $(10 \mathrm{x}), 2.5 \mu \mathrm{l}$ de BSA at 10 $\mu \mathrm{g} / \mu \mathrm{l}$ (BioLabs), $0.5 \mu \mathrm{l}$ of $\mathrm{MgC}_{12}(50 \mathrm{mM}), 1 \mu \mathrm{l}$ of dNTP (10 mM), 0.5 $\mu \mathrm{l}$ of each primer, $0.5 \mu \mathrm{l}$ of Pfu turbo (Stratagene), and $21 \mu \mathrm{l}$ of SDW. The cycling conditions were as follows: enzyme activation at $95^{\circ} \mathrm{C}$ for 2 $\mathrm{min}, 35$ cycles of denaturation at $95^{\circ} \mathrm{C}$ for $30 \mathrm{~s}$, hybridization for $30 \mathrm{~s}$ at $58^{\circ} \mathrm{C}$ for fungal and at $61^{\circ} \mathrm{C}$ for bacterial primers, extension at $72^{\circ} \mathrm{C}$ for $1 \mathrm{~min}$, and final extension at $72^{\circ} \mathrm{C}$ for $10 \mathrm{~min}$.

Genetic structure of the fungal and bacterial communities inhabiting the rhizosphere of treated tomato plants

The PCR products were visualized by $2 \%$ Tris-borate-EDTA agarose gel electrophoresis prior to SSCP analysis. The lengths of the fragments yielded by amplification DNAs were $250 \mathrm{bp}$ for fungi and $350 \mathrm{bp}$ for bacteria. SSCP analyses were performed on an ABI Prism 3130 genetic analyzer (Applied Biosystems) using four 36-cm-long capillary. One $\mu \mathrm{l}$ of a PCR product was mixed with $18.8 \mu \mathrm{Hi}$-Di formamide (Applied Biosystems) and $0.2 \mu \mathrm{l}$ of the internal standard DNA molecular weight marker Genescan $400 \mathrm{HD}$ ROX (Applied Biosystems). The sample was then denatured for $5 \mathrm{~min}$ at $95^{\circ} \mathrm{C}$ and placed directly on ice for $10 \mathrm{~min}$ before being loaded onto the instrument.

CE-SSCP is based on the electrophoretic mobility of singlestranded DNA fragments. This mobility is different according to their three-dimensional conformation. The samples were then allowed to co-migrate with the fluorescent size standard (GeneScan 400 ROX) to enable comparison of migration profiles between samples. Patterns were aligned with the Stat Fingerprints program [39] and studied by principal component analysis (PCA) using R software (version 2.15.2).

\section{Structure and diversity analysis of microbial community}

The characterization of the rhizospheric microbial (fungi and bacteria) communities' structure and diversity was performed with profiles obtained using the CE-SSCP method, as previously described $[39,40]$. All readable molecular fingerprint profiles were aligned with the internal ROX ladder and normalized, to produce relative abundance data with the R package Stat fingerprints v1.3 software. This yielded a matrix in which root samples were indicated in rows, and fluorescence values (4866 scans) in columns. A fluorescence profile may be seen as a quantitative descriptor of the microbial assemblage of a sample. Bigger differences in fluorescence scans between profiles indicate a greater dissimilarity in composition between samples $[39,40]$.

Diversity of rhizosphere microbial (fungi and bacteria) community was evaluated using Fingerprint molecular profiles studied using PCA in relation to environmental factors with $\mathrm{R}$ software (version 2.15.2, including FACTOMINER packages).

In total, 132 samples were analyzed i.e. 66 fungal amplicons (obtained using ML1 and ML2 primers) and 66 bacterial amplicons (obtained using primers 799f and 1115r).

\section{Results}

The PGPR strains B. thuringiensis str. B2, B. subtilis str. B10, and E. cloacae str. B16 were evaluated either separately or in combination for their ability to suppress Rhizoctonia Root Rot and to enhance plant growth on two tomato cultivars under greenhouse conditions in two cropping seasons (2012 and 2013).

\section{Suppression of Rhizoctonia Root Rot using tomato-associated rhizobacteria}

Rhizoctonia Root Rot incidence, noted 60 days post-planting and estimated based on the presence of root browning signs, varied from 0 to $100 \%$ depending on antagonistic treatments tested. It should

\begin{tabular}{|c|c|c|c|c|c|c|}
\hline \multicolumn{2}{|c|}{ Molecular identificatio } & \multicolumn{2}{|c|}{ Antibiotic biosynthesis genes detected } & \multicolumn{3}{|c|}{ PGPR traits } \\
\hline Strains & Accession No. & Fen A & Bac D & IAA & P. Solubilization & Siderophore production \\
\hline Bacillus thuriengiensis B2 & KU158884 & - & + & + & + & ++ \\
\hline B. subtillis $\mathrm{B} 10$ & KT921327 & + & + & + & + & +++ \\
\hline Enterobacter cloacae B16 & KT921429 & + & + & + & + & +++ \\
\hline
\end{tabular}

Table 1: The selected tomato-associated rhizobacteria tested and their main traits.

Fen A: Fengycin A, Bac: Bacillomycin, IAA: Indole acetic acid, P.solubilization: Phosphate solubilization. All isolates were negative for hypersensitive reaction (HR) on tobacco leaves, and they were negative for the detection of Fengycin B, D and E. Positive reaction ( + ); Negative reaction ( - ); Production of siderophore was scored as non detected $(-)$, low $(+)$, middle $(++)$ and high $(+++)$. 
Citation: Ouhaibi-Ben Abdeljalil N, Renault D, Gerbore J, Vallance J, Rey P, et al. (2016) Comparative Efficacy of Three Tomato-Associated Rhizobacteria used Singly or in Combination in Suppressing Rhizoctonia Root Rot and Enhancing Tomato Growth. J Microb Biochem Technol 8: 110-119. doi: 10.4172/1948-5948.1000272

mentioned that all tomato plants not challenged with pathogen remained symptomless but for infected plants, disease incidence noted in 2012 and 2013 (Table 2) ranged between 58.33 and 100\% for cv. Marmande and between 53.33 and 100\% for cv. Rio Grande.

Assessed for their ability to suppress disease severity, all rhizobacteria- and fungicide-based treatments had significantly decreased the root browning index as compared to $R$. solaniinoculated and untreated control. All bacterial strains tested singly or in combination, were found to more effective in suppressing disease than the fungicide on both cultivars and in both cropping seasons. In fact, data shown in Table 3 indicated that disease index noted on cv. Marmande was reduced by 70.02 to $83.94 \%$ in 2012 and by 68.68 to $74.72 \%$ in 2013 compared to $46 \%$ achieved using fungicide. For cv. Rio Grande, disease severity decrease reached using rhizobacteria-based treatments ranged between 60.46 and $77.51 \%$ in 2012 and between 76.06 and $85.01 \%$ in 2013 versus $29.45-52.34 \%$ obtained using fungicide.

Comparative efficacy of bacterial treatments tested in suppressing Rhizoctonia Root Rot was found to be variable depending on bio agents used singly or combined, cultivars grown, and cropping years. In fact, data given in Table 3 showed that three-strain mixture exhibited significantly similar or higher effectiveness in decreasing disease severity as compared to single-strain-based treatments. In fact, in 2013 , all bacterial strains applied singly displayed significantly comparable effectiveness as their mixture but in 2012, plant protection was significantly higher with mixture than with single treatments on $\mathrm{cv}$. Rio Grande whereas B. thuringiensis str. B2- and E. cloacae str. B16-based treatments behaved significantly similar as the combined formulation. It should be highlighted that, for combined data of cultivars and years, disease suppression ranged between 74.72 and $83.94 \%$ using three- strain mixture compared to $60.46-85.01 \%$ achieved using single-strainbased treatments.

\section{Growth promotion using tomato-associated rhizobacteria}

The rhizobacterial strains tested singly or in mixture were assessed for their plant growth-promoting (PGP) abilities based on various growth parameters and their efficacy was compared to $R$. solaniinoculated or not and untreated controls and to a fungicide-based treatment. ANOVA analysis revealed that the plant height, the aerial part and roots fresh weights varied significantly $(P \leq 0.05)$ depending on antagonistic treatments tested, tomato cultivars and cropping years. Their relative effects on each parameter were detailed below.

\section{Plant height promotion}

Plant height variation depending on treatments tested, tomato cultivars grown and cropping years (2012 and 2013) was illustrated in Table 4. In fact, for uninoculated (disease free) and untreated cv. Marmande plants, height increase, as compared to the untreated control, ranged from 13.23 to $32.5 \%$ in 2012 and from 27.34 to $29.65 \%$ in 2013 using single or combined rhizobacterial strains where the highest increment (32.5\%) was achieved using B. subtilis str. B10. For disease free $\mathrm{cv}$. Rio Grande plants, height improvement varied between 31.5 and $45.69 \%$ in 2012 and between 7.55 and $17.02 \%$ in 2013 where the highest PGPR effect was achieved using B. thuringiensis str. B2, E. cloacae str. B16 and the mixed treatment $(\mathrm{B} 10+\mathrm{B} 2+\mathrm{B} 16)$.

Results shown in Table 4 revealed that plants' treatment with strains B. subtilis str. B2, B. thuringiensis str. B10, and E. cloacae str. B16 and the thrre-strain mixture had also significantly enhanced plant height of R. solani-inoculated and treated plants as compared to the untreated

\begin{tabular}{|c|c|c|c|c|c|}
\hline Gene & Name & Sequence (5-'3') & Amlicon size (pb) & Annealing temperature $\left({ }^{\circ} \mathrm{C}\right)$ & References \\
\hline Mitochondrial Large Subunit rDNA & $\begin{array}{l}\text { ML1 } \\
\text { ML2 }\end{array}$ & $\begin{array}{l}\text { FAM-GATCTTTTGCATAATGGGTCAGC } \\
\text { FAM-TATGTTTCGTAGAAAACCAGC }\end{array}$ & 250 & 58 & [37] \\
\hline 16S ANDr & $\begin{array}{l}\text { 799F } \\
1115 R\end{array}$ & $\begin{array}{l}\text { AACMGGATTAGATACCCKG } \\
\text { 6-FAM AGGGTTGCGCTGCTTG }\end{array}$ & 350 & 61 & [38] \\
\hline
\end{tabular}

Table 2: Pairs of universal primers used in the Single Strand Conformation Polymorphism analyses of the rhizosphere fungal and bacterial populations.

*The position corresponds to the 5'-end of primers with Escherichia coli 16 rRNA as reference [62]; F and R correspond to forward and reverse primers, respectively.

\begin{tabular}{|c|c|c|c|c|c|c|c|c|}
\hline \multirow{3}{*}{\begin{tabular}{|l|}
$\begin{array}{l}\text { Tomato cultivars } \\
\text { Cropping years }\end{array}$ \\
Antagonistic treatments tested \\
\end{tabular}} & \multicolumn{4}{|c|}{ cv. Marmande } & \multicolumn{4}{|c|}{ cv. Rio Grande } \\
\hline & \multicolumn{2}{|c|}{2012} & \multicolumn{2}{|c|}{2013} & \multicolumn{2}{|c|}{2012} & \multicolumn{2}{|c|}{2013} \\
\hline & $\begin{array}{l}\text { Disease } \\
\text { Incidence (\%) }\end{array}$ & Disease index & $\begin{array}{l}\text { Disease } \\
\text { Incidence (\%) }\end{array}$ & Disease index & $\begin{array}{l}\text { Disease } \\
\text { Incidence (\%) }\end{array}$ & Disease index & $\begin{array}{l}\text { Disease } \\
\text { Incidence (\%) }\end{array}$ & $\begin{array}{l}\text { Disease } \\
\text { index }\end{array}$ \\
\hline Untreated control* & 0 & 0 e $(100)^{1}$ & 0 & $0.0 d(100)^{1}$ & 0 & $0 \mathrm{f}(100)^{1}$ & 0 & $0.0 \mathrm{~d}(100)^{1}$ \\
\hline B. thuringiensis str. B2 & 0 & 0 e (100) & 0 & $0.0 \mathrm{~d}(100)$ & 0 & $0 \mathrm{f}(100)$ & 0 & $0.0 \mathrm{~d}(100)$ \\
\hline B. subtilis str. B10 & 0 & 0 e (100) & 0 & $0.0 \mathrm{~d}(100)$ & 0 & $0 \mathrm{f}(100)$ & 0 & $0.0 \mathrm{~d}(100)$ \\
\hline E. cloacae str. B16 & 0 & 0 e (100) & 0 & $0.0 \mathrm{~d}(100)$ & 0 & $0 \mathrm{f}(100)$ & 0 & $0.0 \mathrm{~d}(100)$ \\
\hline$B 10+B 2+B 16$ & 0 & 0 e (100) & 0 & $0.0 \mathrm{~d}(100)$ & 0 & $0 \mathrm{f}(100)$ & 0 & $0.0 \mathrm{~d}(100)$ \\
\hline R. solani-inoculated control & 100 & 4.17 a $(0.0)$ & 100 & $4.47 \mathrm{a}(100)$ & 100 & 3.87 a $(0.0)$ & 100 & 4.47 a $(0.0)$ \\
\hline R. solani + B2 & 75 & $1 \mathrm{~cd}(76.02)$ & 93.33 & 1.4 c (68.68) & 93.33 & 1.53 c (60.46) & 80 & 1.07 c (76.06) \\
\hline R. solani + B10 & 83.33 & 1.25 c (70.02) & 93.33 & $1.4 \mathrm{c}(68.68)$ & 93.33 & $1.33 \mathrm{~cd}(65.63)$ & 66.66 & $0.8 \mathrm{c}(82.10)$ \\
\hline R. solani +B16 & 83.33 & $1 \mathrm{~cd}(76.02)$ & 86.66 & 1.20 c (73.15) & 93.33 & $1.33 \mathrm{~cd}(65.63)$ & 53.33 & 0.67 c (85.01) \\
\hline R. solani + B10 + B2 + B16 & 58.33 & $0.67 \mathrm{~d}(83.94)$ & 86.66 & 1.13 c (74.72) & 60 & 0.87 e $(77.51)$ & 60 & 0.8 c (82.10) \\
\hline R. solani+ Fungicide ${ }^{* *}$ & 100 & $2.25 \mathrm{~b}(46.05)$ & 100 & $2.40 \mathrm{~b}(46.30)$ & 100 & 2.73 b (29.45) & 100 & $2.13 \mathrm{~b}(52.34)$ \\
\hline
\end{tabular}

Table 3: Rhizoctonia Root Rot-suppressive effects of three tomato-associated rhizobacteria, tested singly or in combination as compared to fungicide and untreated controls, noted 60 days post-planting on two tomato cultivars and in two cropping years.

Roots necrosis severity was assessed using a $0-5$ scale where: $0=$ no symptom; $1=0-25 \%$ of root browning; $2=26-50 \%$ of root browning; = $51-75 \%$ of root browning; = $76-100 \%$ of root browning, and $5=100 \%$ of root browning (Lamsal et al., 2012)

*Uninoculated and untreated control; ${ }^{* *}$ Fungicide-based treatment using Previcur Energy ${ }^{\mathrm{TM}}$ (632.6 g/l Propamocarb-Hcl $+332.6 \mathrm{~g} / \mathrm{l} \mathrm{Fosethyl-Al)}$.

1: Values in parenthesis indicate the percentage (in \%) of decrease in disease severity as compared to the inoculated and untreated control plants.

For each parameter, values followed by the same letter are not significantly different according to Duncan's Multiple Range tests (at $P \leq 0.05$ ). 
Citation: Ouhaibi-Ben Abdeljalil N, Renault D, Gerbore J, Vallance J, Rey P, et al. (2016) Comparative Efficacy of Three Tomato-Associated Rhizobacteria used Singly or in Combination in Suppressing Rhizoctonia Root Rot and Enhancing Tomato Growth. J Microb Biochem Technol 8: 110-119. doi: 10.4172/1948-5948.1000272

ones (Table 4). In fact, for cv. Marmande, height increase ranged from 65.64 to $83.58 \%$ in 2012 and from 42.91 to $50.25 \%$ in 2013 as compared to 60.88 and $40.56 \%$ achieved using commercial fungicide, respectively. However, for cv. Rio Grande, height increment varied from 69.76 to $75.14 \%$ in 2012 and from 42.28 to $49.46 \%$ in 2013 as compared to 66.02 and $40.74 \%$ obtained with chemical treatment, respectively.

Compared to combined treatment, the three strains tested singly had displayed significantly similar PGP effect as their mixture on both cultivars in 2013 cropping season. However, in 2012, B. subtilis str. $\mathrm{B} 10$ was found to be more active on $\mathrm{cv}$. Marmande when used singly $(83.58 \%)$ than if mixed with the two other strains $(76.74 \%)$ whereas on cv. Rio Grande, the three-strain mixture exhibited the highest PGP effect $(75.14 \%)$ than the three single-strain-based treatments (69.76$71.16 \%)$

\section{Aerial parts' fresh weight promotion}

Aerial parts' fresh weight (APFW), noted 60 days post-planting, varied significantly upon treatments tested, tomato cultivars grown and cropping seasons. In fact, data given in Table 5 indicated that for uninoculated and untreated cv. Marmande plants, APFW was significantly increased, compared to the untreated control, by 78.09 to $82.48 \%$ in 2012 and by 48.52 to $61.69 \%$ in 2013 using single or combined rhizobacterial strains. The highest PGP effect recorded in both years was achieved using $B$. thuringiensis str. B2 and the threestrain mixture. For disease free cv. Rio Grande plants, this growth parameter increment ranged between 33.70 and $42.31 \%$ in 2012 and between 34.51 and $49.29 \%$ in 2013 where the mixed treatment $(\mathrm{B} 10+$ B2 + B16) exhibited the highest PGP effect in both cropping seasons.

Data shown in Table 5 revealed that plants' challenge with $B$. thuringiensis str. B2, B. subtilis str. B10, E. cloacae str. B16, and the three-strain mixture led to significant increase, as compared to $R$. solani-inoculated and untreated control, in APFW of both cultivars tested and in both cropping seasons. In fact, for cv. Marmande, APFW increment ranged from 95.44 to $97.02 \%$ in 2012 and from 48.41 to $64.41 \%$ in 2013 compared to 88.66 and $40.22 \%$ (in 2012 and 2013, respectively) achieved using a fungicide-based treatment. However, for

\begin{tabular}{|c|c|c|c|c|}
\hline \multirow{3}{*}{$\begin{array}{l}\text { Tomato cultivars } \\
\text { Cropping years } \\
\text { Antagonistic treatments tested }\end{array}$} & \multicolumn{2}{|c|}{ cv. Marmande } & \multicolumn{2}{|c|}{ cv. Rio Grande } \\
\hline & 2012 & 2013 & 2012 & 2013 \\
\hline & Plant height $(\mathrm{cm})$ & Plant height $(\mathrm{cm})$ & Plant height $(\mathrm{cm})$ & Plant height $(\mathrm{cm})$ \\
\hline Untreated control* & 26.83 cde $(0.0)^{1}$ & $82.87 \mathrm{c}(0.0)^{1}$ & 28.13 de $(0.0)^{1}$ & $92.93 \mathrm{bcd}(0.0)^{1}$ \\
\hline B. thuringiensis str. B2 & 30.92 bcd (13.23) & 114.06 a (27.34) & 48.46 a (41.95) & $105.07 \mathrm{ab}(11.55)$ \\
\hline B. subtilis str. B10 & $39.75 \mathrm{ab}(32.50)$ & 114.6 a $(27.69)$ & $41.07 \mathrm{~b}(31.50)$ & $100.53 \mathrm{ab}(7.55)$ \\
\hline E. cloacae str. B16 & 32.92 bcd (18.50) & 115.67 a (28.35) & 50.93 a (44.76) & $101.13 \mathrm{ab}(8.10)$ \\
\hline$B 10+B 2+B 16$ & 34.83 bc (22.97) & 117.8 a (29.65) & 51.80 a (45.69) & $112.0 \mathrm{a}(17.02)$ \\
\hline R. solani-inoculated control & $7.5 \mathrm{f}(0.0)^{2}$ & $52.07 \mathrm{~d}(0.0)^{2}$ & $9.13 f(0.0)^{2}$ & 50.40 e $(0.0)^{2}$ \\
\hline R. solani + B2 & 21.83 de (65.64) & 91.27 bc (42.91) & 30.4 de (69.96) & 95.07 bcd (46.98) \\
\hline R. solani + B10 & 45.67 a (83.58) & 93.27 bc (44.17) & 30.2 de $(69.76)$ & $87.33 \mathrm{~cd}(42.28)$ \\
\hline R. solani +B16 & 28.67 bcde $(73.84)$ & 96.93 bc (46.28) & $31.66 \mathrm{~d}(71.16)$ & 99.4 abc (49.29) \\
\hline R. solani + $\mathrm{B} 2+\mathrm{B} 10+\mathrm{B} 16$ & 32.25 bcd (76.74) & $104.67 \mathrm{ab}(50.25)$ & 36.73 c (75.14) & 99.73 abc (49.46) \\
\hline R. solani + Fungicide ${ }^{\star *}$ & 19.17 e $(60.88)$ & 87.6 c (40.56) & 26.87 e (66.02) & $85.06 \mathrm{~d}(40.74)$ \\
\hline
\end{tabular}

Table 4: Plant height enhancement achieved using three tomato-associated rhizobacteria, tested singly or in combination as compared to fungicide and untreated controls, noted 60 days post-planting on two tomato cultivars and in two cropping years.

*Uninoculated and untreated control; **Fungicide-based treatment using Previcur Energy ${ }^{\mathrm{TM}}$ (632.6 g/l Propamocarb-Hcl + $332.6 \mathrm{~g} / \mathrm{Fosethyl-Al)}$

1: Values in parenthesis indicate the percentage (in \%) of increase in plant height as compared to uninoculated and untreated control plants.

2: Values in parenthesis indicate the percentage (in \%) of increase in plant height as compared to Rhizoctonia solani-inoculated and untreated control plants.

For each parameter, values followed by the same letter are not significantly different according to Duncan's Multiple Range tests (at $p \leq 0.05$ ).

\begin{tabular}{|c|c|c|c|c|}
\hline \multirow{3}{*}{$\begin{array}{l}\text { Tomato cultivars } \\
\text { Cropping years } \\
\text { Antagonistic treatments tested }\end{array}$} & \multicolumn{2}{|c|}{ cv. Marmande } & \multicolumn{2}{|c|}{ cv. Rio Grande } \\
\hline & 2012 & 2013 & 2012 & 2013 \\
\hline & APFW (g) & APFW (g) & APFW (g) & APFW (g) \\
\hline Untreated control & $2.02 \mathrm{~cd}(0.0)^{1}$ & 25.23 ef $(0.0)^{1}$ & $29.38 \mathrm{~d}(0.0)^{1}$ & $32.90 \mathrm{c}(0.0)^{1}$ \\
\hline B. thuringiensis str. B2 & $11.53 \mathrm{a}(82.48)$ & $61.1 \mathrm{a}(58.70)$ & $44.32 \mathrm{~b}(33.70)$ & 53.14 b (38.08) \\
\hline B. subtilis str. B10 & 10.42 a $(80.61)$ & $49.74 \mathrm{~b}(49.27)$ & $49.12 \mathrm{a}(40.18)$ & $53.44 \mathrm{~b}(38.43)$ \\
\hline E. cloacae str. B16 & 9.86 a $(79.51)$ & $49.01 \mathrm{~b}(48.52)$ & 48.20 a (39.04) & $50.24 \mathrm{~b}(34.51)$ \\
\hline$B 10+B 2+B 16$ & $9.22 \mathrm{ab}(78.09)$ & 65.86 a $(61.69)$ & 50.93 a (42.31) & 64.88 a (49.29) \\
\hline R. solani-inoculated control & $0.33 \mathrm{~d}(0.0)^{2}$ & $18.23 f(0.0)^{2}$ & $14.19 \mathrm{f}(0.0)^{2}$ & $14.34 \mathrm{~d}(0.0)^{2}$ \\
\hline R. solani + B2 & $9.08 \mathrm{ab}(96.37)$ & 41.06 bc (55.60) & 37.66 c (62.32) & $46.28 \mathrm{~b}(69.01)$ \\
\hline R. solani + B10 & 11.08 a (97.02) & $46.86 \mathrm{~b}(61.09)$ & 36.38 c (60.99) & 37.33 c (61.58) \\
\hline R. solani + B16 & 9.84 a (96.65) & $35.34 \mathrm{~cd}(48.41)$ & 36.29 c (60.89) & 36.40 c (60.60) \\
\hline R. solani+ $\mathrm{B} 10+\mathrm{B} 2+\mathrm{B} 16$ & 7.24 b (95.44) & $51.23 \mathrm{~b}(64.41)$ & 36.58 c (61.20) & $48.61 \mathrm{~b}(70.49)$ \\
\hline R. solani + Fungicide ${ }^{*}$ & 2.91 c (88.66) & 30.50 de (40.22) & 21.42 e (33.75) & 30.36 c (52.76) \\
\hline
\end{tabular}

Table 5: Aerial parts' growth promotion achieved using three tomato-associated rhizobacteria, tested singly or in combination as compared to fungicide and untreated controls, noted 60 days post-planting on two tomato cultivars and in two cropping years.

*Uninoculated and untreated control; **Fungicide-based treatment using Previcur Energy ${ }^{\mathrm{TM}}$ (632.6 g/l Propamocarb-Hcl + 332.6 g/l Fosethyl-Al); APFW: Aerial part fresh weight

1: Values in parenthesis indicate the percentage (in \%) of increase in aerial part fresh weight as compared to uninoculated and untreated control plants.

2: Values in parenthesis indicate the percentage (in \%) of increase in plant height as compared to Rhizoctonia solani-inoculated and untreated control plants.

For each parameter, values followed by the same letter are not significantly different according to Duncan's Multiple Range tests (at $P \leq 0.05$ ). 
Citation: Ouhaibi-Ben Abdeljalil N, Renault D, Gerbore J, Vallance J, Rey P, et al. (2016) Comparative Efficacy of Three Tomato-Associated Rhizobacteria used Singly or in Combination in Suppressing Rhizoctonia Root Rot and Enhancing Tomato Growth. J Microb Biochem Technol 8: 110-119. doi: 10.4172/1948-5948.1000272

cv. Rio Grande, this parameter was enhanced by 60.89 to $62.32 \%$ in 2012 and by 60.60 to $70.49 \%$ in 2013 , using single or mixed bacterial strains compared to 33.75 and $52.76 \%$ recorded on fungicide-treated plants.

Based on their ability to enhance the aerial part growth on $\mathrm{cv}$. Marmande, B. subtilis str. B10 and E. cloacae str. B16 led to significantly higher increase of this parameter ( 97.02 and $96.65 \%$, respectively) than the mixed treatment in 2012 (95.44\%) whereas in 2013 trial, $B$. thuringiensis str. B2 and B. subtilis str. B10 showed significantly similar PGB effect as the three-strain mixture (55.60-64.41\%). However, when tested on cv. Rio Grande, the three strains, applied singly or in mixture, led to significantly similar aerial part growth in 2012 trial whereas in 2013 , only B. thuringiensis str. B2-based treatment was found to be as effective as the three-strain mixture (69.01-70.49\%) in improving this growth parameter.

\section{Root fresh weight promotion}

Root fresh weight (RFW), noted 60 days post-planting, varied significantly upon treatments tested, tomato cultivars grown and cropping seasons as illustrated in Table 6. Indeed, for uninoculated and untreated cv. Marmande plants, RFW was significantly improved, compared to the untreated control, by 89.82 to $92.39 \%$ in 2012 trial and by 60.17 to $75.75 \%$ in 2013 using single or mixed bacterial strains. The highest PGP effect recorded in 2012 was displayed by B. subtilis str. B10, E. cloacae str. B16 and the three-strain mixture (91.21-92.39\%). For disease free cv. Rio Grande plants, root growth increment ranged between 38.78 and $54.16 \%$ in 2012 and between 20.52 and $45.03 \%$ in 2013 trials where the mixed treatment $(\mathrm{B} 10+\mathrm{B} 2+\mathrm{B} 16)$ exhibited the highest PGP effect in both cropping seasons whereas B. subtilis str. B10 and E. cloacae str. B16 were shown to be as effective as the three-strain mixture in 2012 trial.

Results given in Table 6 indicated that bacterial strains, applied singly or in mixture, had significantly $(P \leq 0.05)$ enhanced root development as compared to $R$. solani-inoculated and untreated control, and that their PGP effect varied depending on tomato cultivars grown and cropping years. In fact, for cv. Marmande, RFW was increased by 98.5 to $99.05 \%$ in 2012 and by 73.68 to $76.97 \%$ in 2013 as compared to 66.67 and $65.68 \%$ noted on fungicide-treated plants. However, tested on cv. Rio Grande, root growth enhancement achieved using bacteria-based treatments ranged between 51.50 and $60.82 \%$ in 2012 and between 61.51 and $73.71 \%$ in 2013 relative to 37.83 and $56.32 \%$ obtained using fungicide.

Assessed for their comparative ability to enhance RFW of tomato plants already challenged with $R$. solani, the three strains were shown to be as effective as their mixture on cv. Rio Grande in both cropping seasons (51.50-73.71\%) and on cv. Marmande only in 2013 trial (73.6876.97\%) whereas in 2012, B. subtilis str. B10 and E. cloacae str. B16 exhibited significantly higher PGP effect (98.90-99.05\%) than the combined treatment (98.5\%).

\section{Correlation between Rhizoctonia Root Rot severity and plant growth parameters}

For cv. Marmande data, Pearson's correlation analysis revealed that plant height was significantly and negatively related to disease index in $2012(\mathrm{r}=-0.442 ; P=1.1208 \mathrm{E}-7)$ and $2013(\mathrm{r}=-0.6047 ; P$ $=7.8748 \mathrm{E}-18)$ cropping seasons. This indicates that increased Rhizoctonia Root Rot severity led to plant stunting if compared to the uninoculated control plants. Similar trend was noted between APFW and disease severity index where significant and negative correlations were detected between both dependant variables in $2012(\mathrm{r}=-0.4827 ; P$ $=4.5554 \mathrm{E}-9)$ and $2013(\mathrm{r}=-0.4915 ; P=2.0269 \mathrm{E}-11)$ trials. Also, RFW was found to be negatively related to Rhizoctonia Root Rot index both in $2012(\mathrm{r}=-0.4452 ; P=8.8295 \mathrm{E}-8)$ and 2013 cropping seasons $(\mathrm{r}=$ $-0.5573 ; P=7.4983 \mathrm{E}-15)$.

For cv. Rio Grande, Pearson's correlation analysis also revealed similar significant correlations between disease severity and growth parameters as for $\mathrm{cv}$. Marmande. In fact, plant height was significantly and negatively related to disease index in $2012(\mathrm{r}=-0.6768 ; P=1.8841$ E-23) and 2013 trials $(r=-0.6555 ; P=1.2550$ E21). Also, significant and negative correlation was detected between APFW and disease severity both in $2012(\mathrm{r}=-0.6932 ; P=5.7914 \mathrm{E}-25)$ and 2013 cropping seasons $(\mathrm{r}=-0.5841 ; P=1.7768 \mathrm{E}-16)$. RFW was also found to be significantly and negatively related to Rhizoctonia Root Rot index in $2012(\mathrm{r}=$ $-0.6306 ; P=1.1034 \mathrm{E}-19)$ and $2013(\mathrm{r}=-0.4968 ; P=1.1404 \mathrm{E}-11)$ trials

This analysis indicated that the decreased Rhizoctonia Root Rot severity on tomato plants, achieved using rhizobacteria-based

\begin{tabular}{|c|c|c|c|c|}
\hline \multirow{3}{*}{$\begin{array}{l}\text { Tomato cultivars } \\
\text { Cropping years } \\
\text { Antagonistic treatments tested }\end{array}$} & \multicolumn{2}{|c|}{ cv. Marmande } & \multicolumn{2}{|c|}{ cv. Rio Grande } \\
\hline & 2012 & 2013 & 2012 & 2013 \\
\hline & RFW (g) & RFW (g) & RFW (g) & RFW (g) \\
\hline Untreated control & $0.29 \mathrm{~d}(0.0) 1$ & $1.37 \mathrm{~g} \mathrm{(0.0)1}$ & 3.03 ef $(0.0) 1$ & $3.6 \mathrm{bcd}(0.0) 1$ \\
\hline B. thuringiensis str. B2 & 2.85 bc (89.82) & $4.97 \mathrm{~b}(72.43)$ & $4.95 \mathrm{~b}(38.78)$ & $4.88 \mathrm{~b}(26.22)$ \\
\hline B. subtilis str. B10 & 3.81 a (92.39) & 3.85 c (64.41) & 6.61 a $(54.16)$ & $4.53 \mathrm{~b}(20.52)$ \\
\hline E. cloacae str. B16 & $3.44 \mathrm{abc}(91.57)$ & $3.44 \mathrm{~cd}(60.17)$ & 6.02 a (49.66) & $4.89 \mathrm{~b}(26.38)$ \\
\hline $\mathrm{B} 10+\mathrm{B} 2+\mathrm{B} 16$ & $3.3 \mathrm{abc}(91.21)$ & 5.65 a $(75.75)$ & 6.20 a $(51.12)$ & $6.55 \mathrm{a}(45.03)$ \\
\hline R. solani-inoculated control & $0.04 \mathrm{~d}(0.0) 2$ & $0.70 \mathrm{~h}(0.0) 2$ & $1.61 \mathrm{~g}(0.0) 2$ & 1.07 e $(0.0) 2$ \\
\hline R. solani + B2 & 2.73 bc (98.53) & 2.66 ef $(73.68)$ & $4.11 \mathrm{c}(60.82)$ & $3.86 \mathrm{bc}(72.27)$ \\
\hline R. solani + B10 & $3.64 \mathrm{ab}(98.90)$ & $3.04 \mathrm{de}(76.97)$ & $3.87 \mathrm{~cd}(58.39)$ & $2.97 \mathrm{~cd}(63.97)$ \\
\hline R. solani +B16 & 4.21 a (99.05) & 2.68 ef $(73.88)$ & 3.32 de $(51.50)$ & $2.78 \mathrm{~cd}(61.51)$ \\
\hline R. solani+ B10 + B2 + B16 & 2.66 c (98.5) & 2.71 ef $(74.16)$ & $3.94 \mathrm{~cd}(59.13)$ & $4.07 \mathrm{bc}(73.71)$ \\
\hline R. solani + Fungicide* & $0.12 \mathrm{~d}(66.67)$ & $2.04 \mathrm{f}(65.68)$ & $2.59 \mathrm{f}(37.83)$ & $2.45 \mathrm{~d}(56.32)$ \\
\hline
\end{tabular}

Table 6: Root growth promotion achieved using three tomato-associated rhizobacteria, tested singly or in combination as compared to fungicide and untreated controls, noted 60 days post-planting on two tomato cultivars and in two cropping years.

*Uninoculated and untreated control; **Fungicide-based treatment using Previcur Energy ${ }^{\mathrm{TM}}$ (632.6 g/l Propamocarb-Hcl + $332.6 \mathrm{~g} / \mathrm{l} \mathrm{Fosethyl-Al);} \mathrm{RFW:} \mathrm{Root} \mathrm{fresh} \mathrm{weight}$ 1: Values in parenthesis indicate the percentage (in \%) of increase in root fresh weight as compared to uninoculated and untreated control plants.

2: Values in parenthesis indicate the percentage (in \%) of increase in plant height as compared to Rhizoctonia solani-inoculated and untreated control plants.

For each parameter, values followed by the same letter are not significantly different according to Duncan's Multiple Range tests (at $P \leq 0.05$ ) 
Citation: Ouhaibi-Ben Abdeljalil N, Renault D, Gerbore J, Vallance J, Rey P, et al. (2016) Comparative Efficacy of Three Tomato-Associated Rhizobacteria used Singly or in Combination in Suppressing Rhizoctonia Root Rot and Enhancing Tomato Growth. J Microb Biochem Technol 8: 110-119. doi: 10.4172/1948-5948.1000272

treatments applied singly or in combination, was related to the registered aerial parts and root growth promotion.

\section{Genetic structure of the fungal and bacterial communities inhabiting the rhizosphere of treated tomato plants}

A total of 132 SSCP profiles (66 for rhizobacteria and 66 for fungi) were generated from root samples collected from tomato cvs. Marmande and Rio Grande plants during 2013 cropping season. According to the number of peaks and the relative height of the baseline, the SSCP profiles revealed complex microbial community (data not shown)

Principal Component Analyses (PCAs) were carried out to compare the genetic structure of bacterial and fungal communities colonizing the rhizosphere of the two tomato cultivars inoculated with Rhizoctonia solani and treated with different rhizobacterial strains applied singly or in combination. The distributions of the samples on the principal plans generated by the PCA analysis of fungal and bacterial communities are represented in Figure 1. PCA eigenvalues indicate that the first two principal components, Dim1 and Dim2, account for 62 and $82 \%$ of the total variability respectively for fungi and rhizobacteria. In both cases, microbial community differed only depending on cultivars grown. No differences in the genetic structure were observed when neither the rhizobacteria treatment nor the pathogen inoculation was considered (data not shown).

\section{Discussion}

Biocontrol of soil borne plant diseases has become an important approach for creating a long-lasting effect and facilitating sustainable agriculture as it is one of the viable alternatives to chemical control [2]. In a previous work, among several rhizobacteria recovered from tomato rhizosphere, three strains were selected for their ability to suppress Sclerotinia Stem Rot and Rhizoctonia Root Rot diseases (8,unpublished data) and to enhance plant growth, namely B. thuringiensis str. B2 (KU158884), B. subtilis str. B10 (KT921327) and E. cloacae str. B16 (KT921429). In the present study, these strains were tested singly or in mixture for bioprotection against Rhizoctonia Root Rot disease and plant growth-promoting in two tomato cultivars tested in two cropping seasons.

The three analyzed rhizobacterial antagonists were shown to be a promising alternatives to the commercial fungicide i.e. Previcur Energy $^{\mathrm{TM}}$ (632.6 g/l Propamocarb-Hcl $+332.6 \mathrm{~g} / \mathrm{l}$ Fosethyl-Al), which is routinely used to protect horticultural crops and particularly in suppressing Rhizoctonia Root Rot on pot-grown tomato. However, there is other examples in the literature in which rhizobacteria were reported to more effective than fungicides in increasing plant defense against $R$. solani $[11,41]$.

The three strains tested in the current study were previously shown to be Fengycin A- and/or Bacillomycin D-producing agents (Table 1). This antibiotic synthesis ability may be involved in the observed disease-suppressive effects. This mechanism of action is reported to be more effective than any other mechanism and microorganisms acting through antibiosis were known to have a wide spectrum action [42].

The three strains tested (B. thuringiensis str. B2, B. subtilis str. B10, and E. cloacae str. B16) and their mixture had protected tomato plants from $R$. solani infection. Their disease-suppression effect against $R$. solani was significant on both cultivars tomato plants as compared to control treatments and in both cropping seasons. In fact, as reported in previous studies, where Bacillus spp. and Enterobacter spp. or and their by-products are applied to plants, the outcome is disease control $[43,44]$. Moreover, B. subtilis strains are known to inhibit several soil borne diseases such as Rhizoctonia Root Rot $[13,45]$.

This study clearly demonstrated that some strains exhibited comparable, lower or higher effectiveness when used singly than when applied in mixture with the other two strains. This may be explained by synergistic or antagonistic interaction between mixed BCAs that impacts their relative modes of action and the additive effects of antifungal metabolites produced as previously demonstrated by Patel et al. [46]. The results showed that some individual and compatible mixtures of PGPR strains could provide a broad spectrum activity against the targeted pathogen.
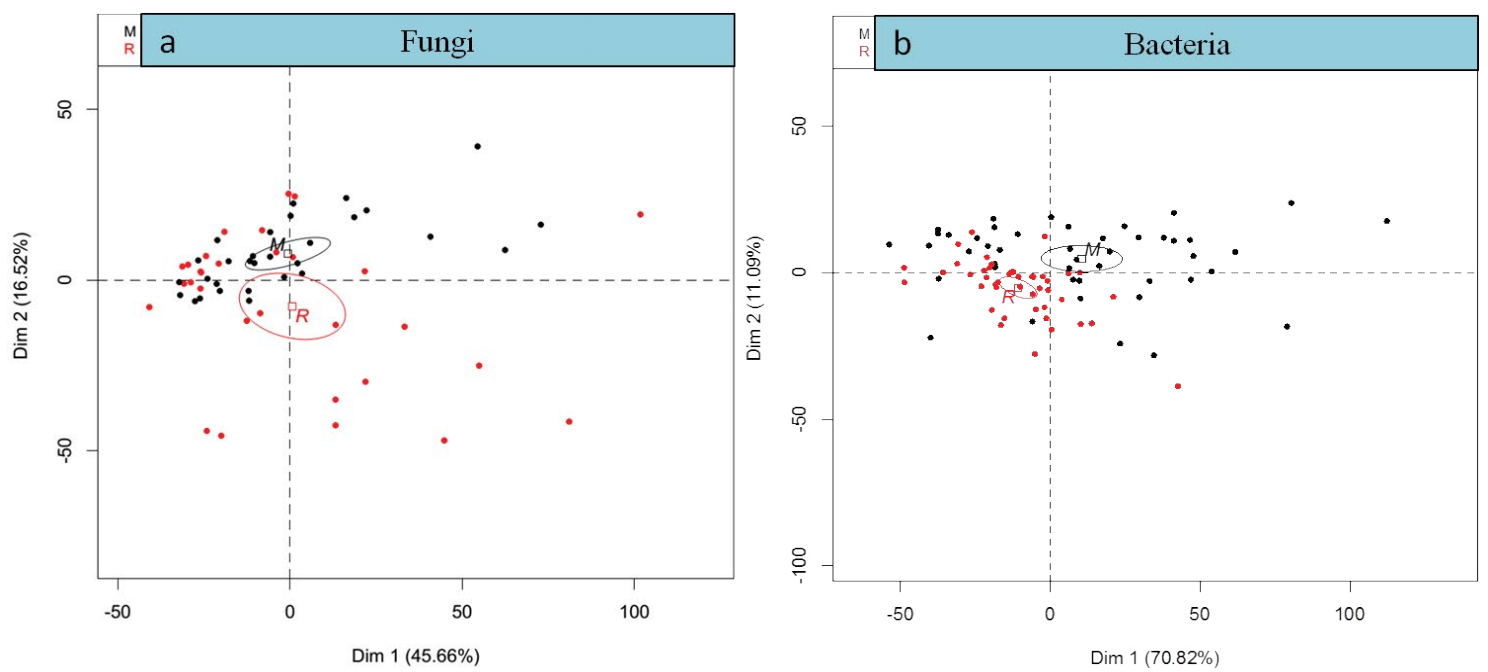

Figure 1: Principal Component Analysis (PCA) of the fungal (a) and bacterial (b) communities inhabiting the rhizosphere of two tomato cultivars (R: Rio Grande (red) and M: Marmande (black)) based on SSCP profiles.

The variation (\%) explained by each PCA axis is given in brackets. Ellipses represent the $95 \%$ confidence intervals calculated for each community. 
The application of PGPR is a potentially attractive approach to disease management and improved crop productivity in agriculture. In many cases and based on some disease and growth indicators, combination of rhizobacterial strains was found to be more or as effective as single strains in decreasing disease incidence and severity and in enhancing plant height, aerial part and root fresh weights. The efficacy of these strains differed depending on bioagents used, cultivar grown, and cropping years. All tomato plants not challenged with $R$. solani remained symptomless. In fact, results showed that strains' mixture exhibited significantly similar or higher effectiveness in decreasing disease severity as compared to single--strain-based treatments. For combined data of both cultivars and years, disease suppression ranged between 74.72 and $83.94 \%$ with mixture compared to $60.46-85.01 \%$ achieved using single strains. The results are consistent with other findings demonstrating that the use of antagonistic agents mixtures have a good protective effect against various soilborne fungal pathogens [29,32]. In fact, a combination of antibiotic-producing strains may act synergistically in restricting the growth and colonization of pathogens $[47,48]$.

Results from our study indicate that the individual PGPR strains applied as a substrate drench had significantly lowered disease severity incited by $R$. solani on two tomato cultivars grown under greenhouse conditions, and that the three-strain mixture, also applied as a soil drench, had further increased the efficacy of disease control against the targeted pathogen. Several other studies have also demonstrated the reliability of effective disease suppression by combined use of PGPR strains $[32,49]$. Treatment of tomato seeds with PGPR and especially using mixtures of bacterial strains B125 + PT42 and PT42 + SZ141 have significantly decreased Rhizoctonia damping-off in mini-chamber tests [50]. Also, Szczech and Shoda [51] have proved the enhanced consistency of disease resistance using mixtures of $B$. subtilis RB14-C and Burkholderia cepacia BY strains against $R$. solani of tomato plants under under growth chamber conditions. Jetiyanon et al. [29] noted similar additive efficacy using mixtures of two PGPR strains namely B. amyloliquefaciens str. IN937a and B. pumilus str. IN937b under field conditions which consistently protected several different crop species against multiple diseases more than that recorded using strains singly. This synergistic effect obtained with mixtures had subsequently enhanced plant growth and yield.

The reduction of disease incidence and severity using BCAs may involve activation of plant defense mechanism against pathogens or production of a wide range of allelochemicals or secondary compounds that may act as antifungal agents and/or as signals such as siderophores, antibiotics, volatile metabolites, and enzymes $[23,52]$.

This study clearly demonstrated the ability of the bacterial strains, applied singly or in mixtures, to promote plant growth as estimated based on plant height and fresh weight of aerial parts and roots. In fact, the mixed treatment $(\mathrm{B} 10+\mathrm{B} 2+\mathrm{B} 16)$ and single treatment using B. subtilis str. B10 exhibited the highest PGP effect, as compared to uninoculated and to $R$. solani-inoculated and untreated controls in the most cases. Thus, data from this study highlighted the additional growth-promoting effects displayed by these strains, tested singly or in combination, when challenged to tomato plants already infected with $R$. solani. Indeed, a successful biocontrol agent is generally equipped with several attributes which often promote plant growth as efficiently as it inhibited fungal growth by efficient root colonization, phytohormone production and nutrient competition [25].

Results from the current study showed that the growth parameters of treated tomato plants were significantly increased in comparison with the control treatments. This increase could be attributed to the aforementioned role of these microorganisms and to their ability to produce lipopeptide antibiotics, IAA, and siderophore and to solubilize phosphate (Table 1). In fact, the improvement of plant growth could result from substances, released by biocontrol agents during their growth on and around plant roots, acting as growth regulators and/ or through making certain nutrients more available leading to plant growth stimulation $[16,53,54]$. The promotion of tomato growth parameters by $B$. subtilis, B. thuringiensis and E. cloacae may be due to their abilities to produce phytohormones, vitamins and solublizing minerals besides, their role in direct inhibition of pathogen growth [55]. Several previous works have demonstrated the additive PGP effect using strains in mixture belonging to Bacillus spp. including $B$. subtilis, $B$. amyloliquefaciens, but to our knowledge, the synergistic effect between $B$. subtilis, $B$. thuringiensis and E. cloacae was not widely reported. Combined bacterial applications can also lead to increased root surface area and general architecture change [56]. Consequently, the use of bacteria to achieve an appropriate and effective biological control of $R$. solani relies on their ability to colonize roots efficiently; otherwise, their biocontrol character would be non-sense. The ability to colonize roots is highly variable depending on rhizobacterial species, indicating their variable ability to compete for ecological niches in the rhizosphere [48,57].

Shifts occurring within microbial community structure in response to inoculation have been reported in various studies performed with symbiotic rhizosphere bacteria $[58,59]$. The microbial interaction in the rhizosphere of tomato cvs. Marmande and Rio Grande roots with pathogen and bacterial treatments challenge was elucidated using PCR-SSCP. This technique was commonly used for analysis of the bacterial and fungal populations of roots removed from treated and untreated tomato plants. As revealed by PCR-SSCP structural analyses of the microbial rhizosphere, one of the main points of our study is that there are significant differences between the microbial communities from bacteria-amended and untreated control treatments. This last assumption was verified when the dynamics of the genetic structure of the rhizosphere fungal communities were characterized by SSCP. It is a key point in the management of this microflora and therefore in determining its future success or failure.

The genetic structure of the microbial community in the rhizosphere of the tomato plants was found to be similar and no differences were observed between the SSCP profiles when neither the rhizobacteria treatment nor the pathogen inoculation was considered. In both cases, microbial communities differed only depending on tomato cultivar grown (Rio Grande or Marmande). There is a clear relationship between cultivated plants and the establishment of the introduced rhizosphere microflora. This relationship may be attributed to the variable release of organic compounds by roots of both cultivars since the SSCP-community patterns of cvs. Marmande and Rio Grande were clearly different from each other. Thus, this study clearly demonstrated that each grown cultivar is able to select its own specific microorganism's community. These results corroborate other findings based on rRNA gene profiling techniques and community-level physiological profiles which demonstrated that plant cultivars are more important in the selection of bacterial communities in rhizosphere than other factors such as soil origin or agricultural systems [60]. The survival of challenged fungal and bacterial strains and their subsequent impact on the indigenous microbial communities' structure is of great interest before using selected natural microorganisms as biocontrol agents under field conditions [61]. Moreover, SSCP analysis of these selected strains did not reveal an adverse impact on nontarget bacterial 
Citation: Ouhaibi-Ben Abdeljalil N, Renault D, Gerbore J, Vallance J, Rey P, et al. (2016) Comparative Efficacy of Three Tomato-Associated Rhizobacteria used Singly or in Combination in Suppressing Rhizoctonia Root Rot and Enhancing Tomato Growth. J Microb Biochem Technol 8: 110-119. doi: 10.4172/1948-5948.1000272

populations. Therefore, these strains released in the rhizosphere of tomato were able to colonize roots and to persist in the rhizosphere without inducing adverse shifts in indigenous populations.

\section{Conclusion}

This study clearly demonstrated the beneficial effects of the selected tomato-associated rhizobacterial strains, applied singly or in combination, in suppressing disease and enhancing plant growth and revealed a variation in rhizosphere microbial community, assessed under controlled conditions, depending on tomato cultivars grown. The effectiveness of these strains and their mixture will be further evaluated under field conditions, in naturally infected soils, based on disease, growth and yield parameters together with the follow up of eventual shifts in rhizosphere microbial activity and structure.

\section{References}

1. Anderson NA (1982) The genetics and pathology of Rhizoctonia solani. Ann Rev Phytopathol 20: 329-347.

2. Goudjal Y, Toumatia O, Yekkour A, Sabaou N, Mathieu F, et al. (2014) Biocontrol of Rhizoctonia solani damping-off and promotion of tomato plant growth by endophytic actinomycetes isolated from native plants of Algerian Sahara. Microbiol Res 169: 59-65.

3. Jiskani MM, Pathan MA, Wagan KH, Imran M, Abro H (2007) Studies on the control of tomato damping-off disease caused by Rhizoctonia solani Kuhn. Pak J Bot 39: 2749-2754.

4. Arora NK, Khare E, Oh JH, Kang SC, Maheshwari DK (2008) Diverse mechanisms adopted by fluorescent Pseudomonas PGC2 during the inhibition of Rhizoctonia solani and Phytophthora capsici. World J Microbiol Biotechnol 24: $581-585$

5. Daami-Remadi M, Zammouri S, El Mahjoub M (2008) Effect of the level of seed tuber infection by Rhizoctonia solani at planting on potato growth and disease severity. Afr J Plant Sci Biotechnol 2: 34-38.

6. Djébali N, Tarhouni B (2010) Field study of the relative susceptibility of eleven potato (Solanum tuberosum L.) varieties and the efficacy of two fungicides against Rhizoctonia solani attack. Crop Prot 29: 998-1002.

7. Khaldi R, Daami-Remadi M, Chérif M (2016) Biological control of stem canker and black scurf on potato by date palm compost and its associated fungi. $J$ Phytopathol 164: 40-51.

8. Ouhaibi-Ben Abdeljalil N, Vallance J, Gerbore J, Rey P, Daami-Remadi M (2016) Bio-suppression of Sclerotinia Stem Rot of tomato and biostimulation of plant growth using tomato-associated rhizobacteria. J Plant Pathol Microbiol 7: 331 .

9. Prashar P, Kapoor N, Sachdeva S (2013) Isolation and characterization of Bacillus sp. with in-vitro antagonistic activity against Fusarium oxysporum from rhizosphere of tomato. J Agric Sci Technol 15: 1501-1512.

10. Huang X, Zhang N, Yong X, Yang X, Shen Q (2012) Biocontrol of Rhizoctonia solani damping-off disease in cucumber with Bacillus pumilus SQR-N43. Microbiol Res 167: 135-143.

11. Scherwinski K, Grosch R, Berg G (2008) Effect of bacterial antagonists on lettuce: active biocontrol of Rhizoctonia solani and negligible, short-term effects on nontarget microorganisms. FEM Microbiol Ecol 64: 106-116.

12. Whipps JM (2001) Microbial interactions and biocontrol in the rhizosphere. J Exp Bot 52: 487-511.

13. Montealegre JR, Reys R, Perez LM, Herrera R, Silva P, et al. (2003) Selection of bioantagonistic bacteria to be used in biological control of Rhizoctonia solani in tomato. Elect J Biotechnol 6: 115-127.

14. Labuschagne N, Pretorius T, Idris AH (2010) Plant growth promoting rhizobacteria as biocontrol agents against soilborne plant diseases. Microbio Monog 18: 211-230.

15. Lamsal K, Kim SW, Kim YS, Lee YS (2012) Application of Rhizobacteria for Plant Growth Promotion Effect and Biocontrol of Anthracnose Caused by Colletotrichum acutatum on Pepper. Mycobiology 40: 244-251.

16. Sasirekha B, Ashwini, Shivakumar S (2012) Multifarious antagonistic potentials of rhizosphere associated bacterial isolates against soil borne diseases of Tomato. Asian J Plant Sci Res 2: 180-186.

17. Basurto-Cadena MG, Vázquez-Arista M, García-Jiménez J, Salcedo-Hernández $\mathrm{R}$, Bideshi DK, et al. (2012) Isolation of a new Mexican strain of Bacillus subtilis with antifungal and antibacterial activities. ScientificWorldJournal 2012 : 384978 .

18. Marín VM, Olvera HAL, Coronado CFS, Alférez BP, Ramos LHM, et al. (2008) Antagonistic activity of selected strains of Bacillus thuringiensis against Rhizoctonia solani of chili pepper. Afr J Biotechnol 7: 1271-1276.

19. Velusamy P, Kim KY (2011) Chitinolytic activity of Enterobacter sp. KB3 antagonistic to Rhizoctonia solani and its role in the degradation of living fungal hyphae. Int Res J Microbiol 2: 206-214.

20. Shahab S, Ahmed N, Khan NS (2009) Indole acetic acid production and enhance growth promotion by indigenous PSBs. Afr J Agric Res 11: 1312-1316.

21. Kumar A, Kumar A, Devi S, Patil S, Payal Ch, et al. (2012) Isolation, screening and characterization of bacteria from rhizospheric soils for different plant growth promotion (PGP) activities: an in vitro study. Recent Res Sci Technol 4: 1-5.

22. Vander S, Verhagen M, Van R, Bakker D, Verlaan MG, et al. (2008) MYB72 is required in early signaling steps of rhizobacteria-induced systemic resistance in Arabidopsis. Plant Physiol 146: 1293-1304.

23. Saharan BS, Nehra V (2011) Plant growth promoting rhizobacteria: A critica review. Life Sciences and Medicine Research 21: 1-30.

24. Berg G, Smalla K (2009) Plant species and soil type cooperatively shape the structure and function of microbial communities in the rhizosphere. FEMS Microbiol Ecol 68: 1-13

25. Saraf M, Pandya U, Thakkar A (2014) Role of allelochemicals in plant growth promoting rhizobacteria for biocontrol of phytopathogens. Microbiol Res 169 : 18-29.

26. Latha P, Anand T, Prakasam V, Jonathan EI, Paramathma M (2011) Combining Pseudomonas, Bacillus and Trichoderma strains with organic amendments and micronutrient to enhance suppression of collar and root rot disease in physic nut. Appl Soil Ecol 49: 215-223

27. Nandakumar R, Babu S, Viswanathan R, Sheela J, Raguchander T (2001) A new bio-formulation containing plant growth promoting rhizobacterial mixture for the management of sheath blight and enhanced grain yield in rice. BioControl 46: 493-510.

28. Jetiyanon K, Kloepper JW (2002) Mixtures of plant growth-promoting rhizobacteria for induction of systemic resistance against multiple plant diseases. Biol Control 24: 285-291.

29. Jetiyanon K, Fowler WD, Kloepper JW (2003) Broad-spectrum protection against several pathogens by PGPR mixtures under field conditions in Thailand Plant Dis 87: 1390-1394.

30. Domenech J, Reddy MS, Kloepper JW, Ramos B, Gutierrez J (2006) Combined application of the biological product LS213 with Bacillus, Pseudomonas or Chryseobacterium for growth promotion and biological control of soil borne diseases in pepper and tomato. BioControl 51: 245-258.

31. Sundaramoorthy S, Raguchander T, Ragupathi N, Samiyappan R (2012) Combinatorial effect of endophytic and plant growth-promoting rhizobacteria against wilt disease of Capsicum annum $L$. caused by Fusarium solani. Biol Control 60: 59-67.

32. Thilgavathi R, Saravanakumar D, Ragupathy N, Samiyappan R (2007) Integration of biocontrol agents for the management of dry root (Macrophomina phaseolina) disease in green gram. Phytopathol Medit 46: 157-167.

33. Senthilraja G, Anand T, Durairaj C, Raguchander T, Samiyappan R (2010) Chitin-based bioformulation of Beauveria bassiana and Pseudomonas fluorescens for improved control of leaf miner and collar rot in ground nut. Crop Prot 29: 1003-1010.

34. Bhai RS, Kishore VK, Kumar A, Anandaraj M, Eapen SJ (2005) Screening of rhizobacterial isolates against soft rot disease of ginger (Zingiber officinale Rosc.). J Spices Arom Crops 14: 130-136.

35. Benchabane M, Bakour R, Toua D, Boutekrabt A (2000) Mise en évidence de l'effet antagoniste de Pseudomonas fluorescens vis-à-vis de la fusariose vasculaire de la tomate. EPPO Bull 30: 243-246.

36. Godon JJ, Zumstein E, Dabert P, Habouzit F, Moletta R (1997) Molecular 
Citation: Ouhaibi-Ben Abdeljalil N, Renault D, Gerbore J, Vallance J, Rey P, et al. (2016) Comparative Efficacy of Three Tomato-Associated Rhizobacteria used Singly or in Combination in Suppressing Rhizoctonia Root Rot and Enhancing Tomato Growth. J Microb Biochem Technol 8: 110-119. doi: 10.4172/1948-5948.1000272

microbial diversity of an anaerobic digestor as determined by small-subunit rDNA sequence analysis. Appl Environ Microbiol 63: 2802-2813

37. White TJ, Bruns TD, Lee S, Taylor J (1990) Analysis of phylogenetic relationships by amplification and direct sequencing of ribosomal RNA genes, Academic Press, New York.

38. Redford AJ, Bowers RM, Knight R, Linhart Y, Fierer N (2010) The ecology of the phyllosphere: geographic and phylogenetic variability in the distribution of bacteria on tree leaves. Environ Microbiol 12: 2885-2893.

39. Michelland RJ, Dejean S, Combes S, Fortun-Lamothe L, Cauquil L (2009) StatFingerprints: a friendly graphical interface program for processing and analysis of microbial fingerprint profiles. Mol Ecol Resour 9: 1359-1363.

40. Kimsé M, Bayourthe C, Monteils V, Fortun-Lamothe L, Cauquil L, et al. (2012) Live yeast stability in rabbit digestive tract: Consequences on the caecal ecosystem, digestion, growth and digestive health. Anim Feed Sci Technol 173 235-243.

41. Naureen Z, Hafeez FY, Hussain J, Al Harrasi A, Bouqellah N, et al. (2015) Suppression of incidence of Rhizoctonia solani in rice by siderophore production rhizobacterial strains based on competition for iron. European Scientific Journal 11: 186-207

42. Leelasuphakul W, Hemmanee P, Chuenchitt S (2008) Growth inhibitory properties of Bacillus subtilis strains and their metabolites against the green mold pathogen (Penicillium digitatum Sacc.) of citrus fruit. Postharvest Bio Technol 48: 113-121.

43. McSpadden Gardener BB (2004) Ecology of Bacillus and Paenibacillus spp. in Agricultural Systems. Phytopathology 94: 1252-1258.

44. Zaidi A, Khan MS, Ahemad M, Oves M (2009) Plant growth promotion by phosphate solubilizing bacteria. Acta Microbiol Immunol Hung 56: 263-284

45. Calvo P, Ormeño-Orrillo E, Martínez-Romero E, Zúñiga D (2010) Characterization of Bacillus isolates of potato rhizosphere from andean soils of Peru and their potential PGPR characteristics. Braz J Microbiol 41: 899-906.

46. Patel M, Sheth U, Hajela P, Joshi B, Animasaun DA (2014) Isolation and diversity analysis of rhizobacteria from sugarcane and its biocontrol potential against Rhizoctonia solani a common plant pathogen. Int J Curr Microbiol App Sci 3: 69-76.

47. Choudhary DK, Johri BN (2009) Interactions of Bacillus spp. and plants--with special reference to induced systemic resistance (ISR). Microbiol Res 164: 493-513.

48. Bouizgarne B (2013) Bacteria for plant growth promotion and disease management. Disease Management 15: 458-490.
49. Kloepper JW, Ryu CM, Zhang S (2004) Induced Systemic Resistance and Promotion of Plant Growth by Bacillus spp. Phytopathology 94: 1259-1266.

50. Szczech M, Dysko J (2008) The possibility to use selected mixtures of PGPR bacteria in tomato cultivation. Veg Crops Res Bull 68: 47-56.

51. Szczech M, Shoda M (2004) Biocontrol of Rhizoctonia damping-off of tomato by Bacillus subtilis combined with Burkholderia cepacia. J Phytopathol 152 549-555.

52. Vance CP, Stone CU, Allan DL (2003) Phosphorus acquisition and use: critica adaptations by plants for securing a nonrenewable resource. New Phytol 157 423-447.

53. Nakkeeran S, Fernando WGD, Siddiqui ZA (2005) Plant growth promoting rhizobacteria formulations and its scope in commercialization for the management of pests and disease. Springer 9: 257-296.

54. Abdel SM, Moustafa YA, Hamed HA (2014) Lactic acid bacteria in the green biocontrol against some phytopathogenic fungi: Treatment of tomato seeds. J Basic Appl Sci Res 4: 1-9.

55. Zaghloul RA, Hanafy A, Neweigy NA, Khalifa A (2007) Application of biofertilization and biological control for tomato production. Microbiology 7: 18-20.

56. Adesemoye AO, Torbert HA, Kloepper JW (2009) Plant growth-promoting rhizobacteria allow reduced application rates of chemical fertilizers. Microb Ecol 58: 921-929.

57. Misaghi IJ, Donndelinger CR (1990) Endophytic bacteria in symptom-free cotton plants. Phytopathology 80: 808-811.

58. Nacamulli C, Bevivino A, Dalmastri C, Tabacchioni S, Chiarini L (1997) Perturbation of maize rhizosphere microflora following seed bacterization with Burkholderia cepacia MCI 7. FEMS Microbiol Ecol 23:183-193.

59. Buyer JS, Teasdale JR, Roberts DP, Zasada IA, Maul JE (2010) Factors affecting soil microbial community structure in tomato cropping systems. Soil Biol Biochem 42: 831-841.

60. Miethling R, Wieland G, Backhaus H, Tebbe CC (2000) Variation of Microbia Rhizosphere Communities in Response to Crop Species, Soil Origin, and Inoculation with Sinorhizobium meliloti L33. Microb Ecol 40: 43-56.

61. Schmalenberger A, Tebbe CC (2002) Bacterial community composition in the rhizosphere of a transgenic, herbicide-resistant maize (Zea mays) and comparison to its non-transgenic cultivar Bosphore. FEM Microbiol Ecol 40: 29-37.

62. Brosius J, Dull TJ, Sleeter DD, Noller HF (1981) Gene organization and primary structure of a ribosomal RNA operon from Escherichia coli. J Mol Biol 148 107-127. 